\title{
METHODS OF LEARNING KITAB KUNING FOR BEGINNERS IN ISLAMIC BOARDING SCHOOL (DAYAH)
}

\author{
Fakhrurrazi $^{1}$, Saliha Sebgag ${ }^{2}$ \\ Fakultas Tarbiyah dan Ilmu Keguruan, Institut Agama Islam Negeri Langsa, Aceh Indonesia ${ }^{1}$ \\ Department of Letters and Arabic Language, University Mohamed Khider of Biskra, Algeria ${ }^{2}$ \\ frazilgs@yahoo.com, saliha.sebgag@univ-biskra.dz
}

\begin{abstract}
This article aims to determine the learning objectives of the Kitab Kuning (Books in Arabic Script used in Pesantren/Dayah) for the beginners of Santri Dayah Darul Huda Langsa City, to find out the responses of students in learning the Kitab Kuning for Santri beginners Dayah Darul Huda Langsa City, and to find out implementation of the method of learning the Kitab Kuning for Santri Dayah Darul Huda Langsa City. This article's research method is a descriptive qualitative research method that produces data in the form of written and oral words of the subject under study. This article results are: The purpose of learning the Kitab Kuning in Dayah Darul Huda Langsa City is to improve students' quality in understanding and reading the Kitab Kuning well. The students' response is outstanding in learning the Kitab Kuning as a lesson that students must follow and must be passed according to the minimum standard of a grade determined by the curriculum and teaching of Dayah. The dominant methods used by teachers are the sorogan and bandongan method. The research implication is how students can read the Kitab Kuning correctly and adequately to achieve the learning objectives according to the institution's wishes.
\end{abstract}

Keywords: Learning Method, Kitab Kuning, Bandongan and Sorogan Methods,

\section{Abstrak}

Penelitian ini bertujuan untuk. Mengetabui tujuan pembelajaran kitab kuning Bagi pemula Santri Dayah Darul Huda Kota Langsa, untuk mengetahui respon santri dalam pembelajaran kitab kuning Bagi Santri pemula Dayah Darul Huda Kota Langsa dan untuk Mengetahui pelaksanaan metode pembelajaran kitab kuning Bagi Santri Dayah Darul Huda Kota Langsa. Metode yang digunakan dalam penelitian ini adalah metode penelitian deskriptif kualitatif yang menghasilkan data berupa kata-kata tertulis maupun lisan dari subjek yang diteliti. Hasil dalam penelitian ini adalab: Tujuan pembelajaran Kitab Kuning di Dayah Darul Huda Kota Langsa adalah untuk meningkatkan kualitas santri dalam memahami, membaca kitab kuning dengan baik, respon santri sangat bagus dalam pembelajaran kitab kuning sebagai pelajaran yang wajib diikuti oleh santri dan wajib lulus sesuai dengan standar minimal nilai yang ditentukan oleh bidang kurikulum dan pengajaran Dayah dan Metode yang dominan digunakan oleh guru adalab metode sorogan dan bandongan. Implikasi dari penelitian ini adalab bagaimana santri mampu membaca kitab kuning dengan baik dan benar sehingga tujuan pembelajaran tercapai sesuai keinginan institusi.

Kata Kunci: Metode Pembelajaran, Kitab Kuning. Metode Sorogan dan Bandongan. 


\section{INTRODUCTION}

As a religiously-based institution, Dayah (Islamic Boarding School) was originally a center for developing Islamic broadcasting values. By providing a religion-based curriculum, Dayah is expected to produce alumni who will become strong religious figures and play their phyletic role in society in general. Law number 20 of 2003 concerning the national education system states that the community is one of the parties responsible for education development ${ }^{1}$.

As one of the stakeholders, the community is expected to provide solutions to various educational problems that occur in our country. Education becomes something interesting to talk about it. Knowledge in Islam is a series of human empowerment processes towards taklif (maturity), both mentally and morally, to carry out the humanitarian function carried as a servant before God and as a preserver (caliph) to the universe ${ }^{2}$.

Indonesia is a country with a majority Muslim population. Islam entered Indonesia around the 13th century, with the spread of Islam in Indonesia; since then, Islamic education institutions have also emerged in Indonesia, including mosques, dayah, and madrassa ${ }^{3}$.

In general, dayab is seen as a subculture that develops unique life patterns according to known and modern 'glasses.' In addition to the leadership factor, Kitab Kuning is an essential factor that characterizes the sub-culture ${ }^{4}$. Aside from being a guideline for religious procedures, the Kitab Kuning also functions by the dayahs as a reference for universal values in addressing all community life challenges. When the Kitab Kuning is used permanently, from generation to generation, as the primary reading source for the pesantren community, which is quite extensive, forming and maintaining that unique tradition is underway ${ }^{5}$.

The religious sciences, educational institutions are explicitly needed to handle it. In Indonesia, the only educational institution that is the oldest and has been recognized for its success in dealing with Islamic teachings is the Dayah, so that the Islamic Boarding School is also defined as the Tafaqquh fi al din institution'.

\footnotetext{
${ }^{1}$ Eti Nurhayati and Yayah Nurhidayah, 'Multicultural Value in the Traditional Islamic Boarding School, Bina Insan Mulia (BIMA), Cirebon, Indonesia', Nadwa 13, no. 1 (29 August 2019): 165-78, https://doi.org/10.21580/nw.2019.1.1.3509; Muhammad Thoyib, 'Charismatic Leader on Developing Visionary Pesantren Bidayatul Hidayah in East Java: Profile and Strategy of Dr. KH. Ahmad Musthofa Kamal's Leadership', Jurnal Pendidikan Islam 7, no. 1 (27 August 2018): 79-99, https://doi.org/10.14421/jpi.2018.71.79-99.

2 Ali Jadid Al Idrus, 'Modernisasi Sistem Manajemen Dan Kurikulum Pondok Pesantren', Jurnal Penelitian Keislaman 12, no. 2 (2016): 141-154; Mas `ud Abdurrahman, From Haramain to Nusantara: An Intellectual Trail of Pesantren Architects (Jakarta: Kencana, 2006).

3 Mujamil Qomar, Pesantren: dari transformasi metodologi menuju demokratisasi institusi (Ciracas, Jakarta: Erlangga, 2005), 70; Martin Van Bruinessen, Tarekat Naqsabandiyah DI Indonesia, 1st ed. (Bandung: Mizan, 1992); Nurcholish Madjid, 'Merumuskan Kembali Tujuan Pendidikan Pesantren', Dalam Dawam Rahardjo, Pergulatan Dunia Pesantren: Membangun Dari Bawah. Jakarta: P3M, 1985, 14.

${ }^{4}$ Nurhayati and Nurhidayah, 'Multicultural Value in the Traditional Islamic Boarding School, Bina Insan Mulia (BIMA), Cirebon, Indonesia'; Ismet Nur, 'Modernization of Integrated Dayah Educational System in Darul Mukhlisin Burnijimet', Episteme: Jurnal Pengembangan Ilmu Keislaman 14, no. 2 (1 December 2019): 333-47, https://doi.org/10.21274/epis.2019.14.2.333-347.

5 Martin Van Bruinessen, Kutab Kuning Pesantren dan Tarekat, 1st ed. (Yogyakarta: Gading Publising, 2012); Nana Herdiana Abdurrahman, 'Character Education in Islamic Boarding School- Based Sma Amanah', Jurnal Pendidikan Islam 2, no. 2 (21 June 2016): 287-305, https://doi.org/10.15575/jpi.v2i2.791.

${ }^{6}$ Damanhuri Damanhuri, 'Kitab Kuning: Warisan Keilmuan Ulama Dan Kontekstualisasi Hukum Islam Nusantara', 'Anil Islam: Jurnal Kebudayaan Dan Ilmu Keislaman 10, no. 2 (1 December 2017): 234-61, https://doaj.org; Hanun Asrohah, 'The Dynamics of Pesantren: Responses Toward Modernity and Mechanism
} 
The hallmark of Dayah as a place of deepening Islamic Religious Knowledge is teaching that uses the Kitab Kuning teaching system (the Book of Salaf) ${ }^{7}$. The Kitab Kuning teaching system applied at Islamic boarding schools is unique because students must learn from bare books written without vowels. That is why to read it, and a student must recognize the Arabic word for word and grammar ${ }^{8}$.

This article aims to see how the pesantren applies the Kitab Kuning learning to beginner students. This article works; the results of previous research on understanding the Kitab Kuning will be carried out. Santri can read the Kitab Kuning as identity. Therefore learning the Kitab Kuning is a characteristic of Dayah. The expertise of a santri can be seen when he can master the Kitab Kuning (turats) ${ }^{10}$. The importance of learning the Kitab Kuning made Dayah innovate with learning methods such as Syaiful Rijal's research that the Kitab Kuning learning method with a combination of wetonan and bandongan ${ }^{11}$.

Al-Rasyidin stated in his research results that each kiai has their own way of teaching the Kitab Kuning ${ }^{12}$. Bermawi complements previous research. Namely, students need high motivation to learn the Kitab Kuning properly. Santri are given the classic motivation found in the Talim al Muta'allim book ${ }^{13}$. The application of Kitab Kuning learning at Pesantren Hidayatullah Ternate using the ceramah method $^{14}$. It is different from the Attarbiyah Sumenep Islamic Boarding School, which applies the bandongan approach to discussion innovation, giving students the freedom to explore and explore ${ }^{15}$.

To effectively learn the Kitab Kuning, Dayah Islah made innovations by adding memorization targets, increasing lesson hours, and a combination of sorogan and rote

in Organizing Transformation', Journal of Indonesian Islam 5, no. 1 (1 June 2011): 66-90, https://doi.org/10.15642/JIIS.2011.5.1.66-90.

${ }^{7}$ Hasbi Indra, 'Salafiyah Curriculum at Islamic Boarding School in the Globalization Era', TARBIYA: Journal of Education in Muslim Society 4, no. 1 (13 June 2017): 74-88, https://doi.org/10.15408/tjems.v4i1.4960.

${ }^{8}$ Zamakhsyari Dhofier, Tradisi pesantren: studi pandangan hidup kyai dan visinya mengenai masa depan Indonesia, Cet. 8 rev (Jakarta: LP3ES, 2011).

${ }^{9}$ Rusdi Rusdi, 'Pengembangan Metode Pembelajaran Kitab Kuning Dalam Mencetak Ahli Fiqh', An Nuba: Jurnal Kajian Islam, Pendidikan, Budaya \& Sosial 5, no. 1 (1 July 2018): 35-66, https://doaj.org.

${ }^{10}$ Abdul Malik Karim Amrullah, 'Kontribusi Karya Tulis Kiai Basori Alwi Terhadap Pengembangan Wawasan Keagamaan Masyarakat', Ulul Albab Jurnal Studi Islam 13, no. 1 (17 September 2013): 35-48, https://doi.org/10.18860/ua.v0i0.2381; Muhammad Anas Ma'arif and Nur Silva Nabila, 'The Contribution Of Kiai Munawwar Adnan Kholil Gresik On Islamic Education', Tribakti: Jurnal Pemikiran Keislaman 31, no. 2 (20 July 2020): 218-36, https://doi.org/10.33367/tribakti.v31i2.1126; Damanhuri, 'Kitab Kuning', 240.

11 Akh Syaiful Rijal, 'Pemakaian Kitab Kuning Dalam Meningkatkan Mutu Pembelajaran Fiqh Di Madrasah Tsanawiyah Berbasis Pesantren Di Pamekasan', Muslim Heritage 2, no. 2 (1 January 2018): 293-316, https://doi.org/10.21154/muslimheritage.v2i2.1113.

${ }^{12}$ Al Rasyidin, 'Pembelajaran Kitab Kuning Di Pesantren Musthafawiyah, Mandailing Natal', Journal of Contemporary Islam and Muslim Societies 1, no. 1 (1 September 2017): 41-67, https://doi.org/10.30821/jcims.v1i1.324.

13 Muhammad Barmawi, 'Peranan Lingkungan terhadap Semangat Belajar dalam Khazanah Kitab Kuning, Edukasia Islamika, 2 March 2017, 134-60, http://ejournal.iainpekalongan.ac.id/index.php/edukasiaislamika/article/view/773.

14 Faizal Bachrong, 'Pembelajaran Kitab Kuning Pada Pondok Pesantren Hidayatullah Ternate', PUSAKA 6, no. 1 (26 November 2018): 105-16, https://doi.org/10.31969/pusaka.v6i1.43.

15 Effendi Chairi, 'Pengembangan Metode Bandongan Dalam Kajian Kitab Kuning Di Pesantren Attarbiyah Guluk-Guluk Dalam Perspektif Muhammad Abid al-Jabiri', Nidhomul Haq : Jurnal Manajemen Pendidikan Islam 4, no. 1 (15 March 2019): 70-89, https://doi.org/10.31538/ndh.v4i1.233. 
methods. ${ }^{1617}$ This article is a differentiator from previous research, namely how Dayab Nurul Huda applies the Kitab Kuning learning optimally in various ways. This study is mainly for beginner santri.

The Kitab Kuning in Dayah covers the sciences of interpretation (Ulumu al-Tafsir), Asbabu al-nuzul, Hadith, Asbabu al-Wurud, Figh, Qawaid al-Fiqbiyah, Taubid, Tasawnf, Nabwu, Sharaf, and Balaghah alone. More than that, although only as a reference to the Dayah literature, the Kitab Kuning also includes the sciences of Manthiq, Falak, Faraidl, Hisab, Adabu al-Babtsi wa al-Munadzarah (discussion method), Thibb, Hayatu al-Hayawan, Thabaqat Ulemas, even cataloging or annotations, for example, the Book of Kasyfu al-Drunun fi Asma'I Kutubi alFunun. $^{18}$

Based on the types of the Kitab Kuning, it can be seen that the Kitab Kuning is an explanation of all branches of science in Islam, because besides discussing the science of tools (nabwu and sharaf), the Kitab Kuning also discusses the science of Islamic Sharia which aims to improve the quality of religious diversity of a Muslim, to be able to establish a good relationship with his Lord (bablu min Allab) through worship, and be able to establish good relations with fellow humans (bablu min annas) and the surrounding environment.

To balance information and methodology in teaching Kitab Kuning, the study of ushul fiqh or mantiq as the essential methodological tool needs to be given a more significant portion than just reading and memorizing. Including, ushul figh needs to be studied as a means of developing rational thinking.

From the facts and urgency mentioned above, reading the Kitab Kuning becomes one of the subjects that must be followed by every student. Because the Kitab Kuning is a basic science for studying religious topics such as Tafsir, Hadith, Fiqh, Usul Figh, Kalam Science, and others. The religious lessons, especially novice students, the proof are required to learn and understand these religious lessons. Therefore, understanding the Kitab Kuning basically can help beginner students in mastering these religious lessons. Some students acknowledge that learning the Kitab Kuning in the Dayah environment is very important, especially for beginner students.

\section{THEORY}

\section{Learning Strategy}

The general strategy is an outline of the direction to act to achieve predetermined $\operatorname{targets}^{19}$. The learning strategy can be interpreted as an available pattern of student educator activities to realize teaching and learning activities to achieve the goals outlined. Or in other

16 Moh Tasi'ul Jabbar, Wahidul Anam, and Anis Humaidi, 'Upaya Kiai Dalam Meningkatkan Kemampuan Membaca Kitab Kuning, EDUDEENA: Journal of Islamic Religious Education 1, no. 1 (29 November 2017), https://doi.org/10.30762/ed.v1i1.446.

${ }^{17}$ Lailatul Fitriyah, Marlina Marlina, and Suryani Suryani, 'Pendidikan Literasi Pada Pembelajaran Kitab Kuning Di Pondok Pesantren Nurul Huda Sukaraja’, Titian Ilmu: Jurnal Ilmiah Multi Sciences 11, no. 1 (1 January 2019): 20-30, https://doi.org/10.30599/jti.v11i1.351.

${ }^{18}$ K. H. M. A. Sahal Mahfudh, Nuansa Fiqh Sosial (Lkis Pelangi Aksara, 2003), 23.

19 Yunus Abidin, Desain Sistem Pembelajaran Dalam Konteks Kurikulum 2013, Cetakan kesatu (Bandung: Refika Aditama, 2014). 
words, teaching and learning strategies are a number of steps that are engineered in such a way as to achieve particular teaching objectives ${ }^{20}$.

Educators who are always involved in the teaching and learning process so that goals can be achieved effectively and efficiently, then mastery of the material alone is not enough. He must master various methods or techniques for delivering the fabric taught and know the abilities of children who receive. The selection of the right methods and techniques requires unique expertise. Educators must be intelligent to possess and use what techniques will be used $^{21}$.

Learning, according to the National Education System Law No.20 of 2003, Chapter I Article 1, Paragraph 20 is the process of interaction of students with educators and learning resources in a learning environment. ${ }^{22}$ According to Brown, learning is acquiring knowledge about a subject or skill by learning, experience, or instruction ${ }^{23}$.

So according to Nazarudin in his book titled Learning management expressed the opinion of Margaret E. Bell Gredler that learning can be interpreted as a set of external events designed to support the internal learning processes. ${ }^{24}$ Learning is a system or process of learning students who are planned, implemented, and evaluated systematically to achieve learning objectives actively, effectively, and innovatively ${ }^{25}$. Learning is complex, meaning that everything in the learning process must be significant, both words, thoughts, and actions ${ }^{26}$.

\section{Kitab Kuning: Books in Arabic Sript Used in Pesantren Milleu}

The Kitab Kuning is another word for the Muslim reference book in Arabic. Because such a book does not use punctuation marks, it is also commonly called a bald book. Although many Kitab Kunings has been translated into Indonesian so that it helps to study their contents, it is admitted that studying the Kitab Kuning through its translation is not as good as studying the source directly because the translation is only one version of its content. The classic book, better known as the Kitab Kuning has a very important role in developing Islamic religious teachings. It shows that the Kitab Kuning is important to study. Islamic scientists write their work in a unique colored book, which is yellowish, which is studied by Madrasas and Islamic Boarding Schools ${ }^{27}$.

${ }^{20}$ Dr. Jeanine M. M Dell'Olio and Dr. Tony Donk, Models of Teaching: Connecting Student Learning with Standards. (Thousand Oaks: SAGE Publications, 2007), http://public.eblib.com/choice/publicfullrecord.aspx?p=996882; Felicitas Biwer et al., 'Fostering Effective Learning Strategies in Higher Education - A Mixed-Methods Study', Journal of Applied Research in Memory and Cognition 9, no. 2 (1 June 2020): 186-203, https://doi.org/10.1016/j.jarmac.2020.03.004.

${ }^{21}$ Harun Serpil, 'Book Review Student-Teacher Interaction in Online Learning Environments', The Turkish Online Journal of Distance Education 18, no. 2 (1 April 2017): 202-7, https://doaj.org.

${ }^{22}$ Undang-Undang Sistem Pendidikan Nasional. 2

${ }^{23}$ H. Douglas Brown, Principles of Language Learning and Teaching (Prentice-Hall, 1987); Wendy Brown et al., 'What Is Important in Theorizing Tolerance Today?', Contemporary Political Theory 14, no. 2 (April 2015): 159_ 96, https://doi.org/10.1057/cpt.2014.44.

${ }^{24}$ Nazarudin Rahman, Regulasi Pendidikan: Menjadi Guru Profesional Pasca Sertifikasi (Yogyakarta: Pustaka Felicha, 2009), 162.

${ }^{25}$ Sitalakshmi Venkatraman, 'A Framework for Implementing TQM in Higher Education Programs', Quality Assurance in Education 15, no. 1 (1 January 2007): 92-112, https://doi.org/10.1108/09684880710723052.

${ }^{26}$ B. R Hergenhahn and Matthew H Olson, Theories of learning = teori belajar, trans. Triwibowo, 6th ed. (Jakarta: Prenada Media Grup, 2016); A. Rusdiana, Konsep Inovasi Pembelajaran (Bandung: Pustaka Setia, 2014).

${ }^{27}$ Bachrong, 'Pembelajaran Kitab Kuning Pada Pondok Pesantren Hidayatullah Ternate'. 
Books that contain Islamic sciences, especially Jurisprudence, written or printed with Arabic letters in Arabic or Javanese Malay, Sundanese, and so on. The book is called the "Kitab Kuning" because it is generally printed on low-quality yellow paper. Sometimes the sheets are loose, so the parts that need to be easily taken. Usually, when studying the students only bring sheets to be studied and do not carry the book as a whole. This is a characteristic of the Kitab Kuning itself, so this book is a unique book to study because it can carry the pages to be studied without having to bring the entire contents of the book ${ }^{28}$.

The Kitab Kuning is a book that is always guided by the Qur'an and the Hadith, and which was written by previous scholars in sheets or in the form of binding both printed on yellow paper and white paper and also is the teachings of Islam which is the result interpretation of the scholars from the existing manuals, as well as new things that came to Islam as a result of the development of Islamic civilization in history.

According to Azyumardi Azra, "The Kitab Kuning has its own distinctive format and" yellowish "paper color. ${ }^{29}$ Judging from the unique color of this book, this book is better known as the Kitab Kuning. But lately, these characteristics have changed. The new printed Kitab Kuning already uses a lot of white paper which is commonly used in the printing world. Also, there are many who are not "bald" anymore because they have been given faith to make it easier for students to read. Most of the Kitab Kunings have been bound. Thus, his physical appearance is no longer easily distinguished from new books which are usually called "al-kutub al-asriyyah" (modern books). The difference lies in the content, systematics, methodology, language, and authors. Even so, the nickname "the Kitab Kuning" remains attached to it.

The Kitab Kuning is studied, especially in pesantren having various kinds of religious knowledge to develop religious teachings and develop religious education for students, so that they have a strong belief in carrying out worship. This Kitab Kuning comes from the Middle East.

In its native region, namely the Middle East, the Kitab Kuning is called "al-kutub alqadimab" (classic books) as a comparison to "al-kutub al-asriyah "(modern books). Circulating in Indonesia (among boarding schools) is very limited in kind. From the group of Sharia sciences, which are very well known are the books of jurisprudence, sufism, tafsir of Koran, hadith, monotheism (aqedah), and tarekh (history of Prophet) (especially sirah Nabawiyyah, the life history of the Prophet Muhammad SAW). From the group of non-religious sciences, which are widely known are books of nerve nerves, which are absolutely necessary as a tool to obtain the ability to read bare books. It can be said that the Kitab Kuning which is widely circulating among Islamic boarding schools is a book that contains the sciences of Shari'a, especially Jurisprudence.

Sharia books such as fiqh, tasauf, tafsir, hadith, monotheism, history of Prophet, and non-syariah books such as nahwu, and shorof. everything is written in Arabic on yellow paper and does not use lines (the bare book) so this book is also called the Kitab Kuning.

${ }^{28}$ Van Bruinessen, Kitab Kuning, 40; Dhofier, Tradisi pesantren, 60; Chairi, 'Pengembangan Metode Bandongan Dalam Kajian Kitab Kuning Di Pesantren Attarbiyah Guluk-Guluk Dalam Perspektif Muhammad Abid al-Jabiri'.

${ }^{29}$ Azyumardi Azra, Pendidikan Islam: Tradisi Dan Modernisasi Di Tengah Tantangan Milenium III (Jakarta: Kencana, 2012), 111. 
There are three general characteristics of the Kitab Kuning. First, the presentation of each material in one subject always begins by presenting sharp definitions, which clearly define boundaries to avoid misunderstanding of the problem under discussion. Second, each material element of the subject is described with all the conditions relating to the object of the subject matter. Third, at the syariah level (comments or comments) the author's argument is also explained, complete with the appointment of the legal source. ${ }^{30}$

The Kitab Kuning from the point of view has several important elements to know, so from this point of view we can know and we can understand the meaning of the Kitab Kuning. Among those perspectives are: 1) The contents mean. 2) Presentation level., 3) The creativity of writing. 4) Apperance description.

In Pesantren generally, the Kitab Kuning is taught with two systems, namely the sorogan and bandongan methods. In teaching in the Soragan system, students one by one in turn facing the Kiai by carrying certain books. The kiai (teacher) reads a few lines from the book and its meaning, then the santri repeats the reading of the kiai. Usually, the sorogan system is carried out by santri who are still junior and limited to small books. The bandongan leraning method is the classical teaching of the Kitab Kuning. All students face kiai together. The kiai reads the contents of the book with sufficient meaning and explanation, while the students listen and record the Kiai's explanation on the edge of the page. This way of learning is most practiced in Islamic boarding schools. With a bandongan system of large books like Sabih al-Bukhari can be finished taught in a relatively short time, such as a month of Ramadan conducted by KH. Hasyim Asy'ari at Pesantren Tebuireng, Jombang ${ }^{31}$.

\section{Sorogan Method of Learning}

Sorogan comes from the word sorog (Javanese) which means forward, because every santri offered his book before the Kiai or his assistant. This sorogan learning method includes individual learning, where a santri deals with a teacher, and there is an interaction of getting to know each other ${ }^{32}$.

This is sorogan stem proved to be very effective as the first stage for a student who aspires to be pious. This system allows a teacher to supervise, assess, and guide the maximum ability of a student in mastering learning material. Sorogan is a learning activity for students that focuses more on developing individual abilities, under the guidance of a cleric or cleric.

The method used is a guided reading strategy, where students come together, then wait in line to wait their turn, read the material taught, the teacher listens and guides the reading and explains as needed. With this sorogan system the relationship between the teacher

\footnotetext{
${ }^{30}$ Wawan Arwani, 'Kiai Pesantren Dan Kontribusinya Dalam Mengembangkan Pluralitas Keberagamaan Dan Toleransi Di Kabupaten Cirebon', Holistik 15, no. 1 (5 April 2016), https://doi.org/10.24235/holistik.v15i1.434.

${ }^{31}$ Syamsul Ma'arif, 'Education as a Foundation of Humanity: Learning from the Pedagogy of Pesantren in Indonesia', Journal of Social Studies Education Research 9, no. 2 (12 May 2018): 104-23, https://bulenttarman.com/index.php/jsser/article/view/256.

32 Agus Syakroni et al., 'Motivation And Learning Outcomes Through The Internet Of Things\$ $\backslash$ mathsemicolon\$ Learning In Pesantren', Journal of Physics: Conference Series 1363 (November 2019): 012084, https://doi.org/10.1088/1742-6596/1363/1/012084.
} 
and the students is very close so that the teacher knows the student's personality more easily and easily evaluates.

\section{Wetonan Method of Learning}

Wetonan, the term weton is derived from the word wektu (Javanese language) which means time, because the study is given at certain times, namely before and or after performing fard prayer. This is weton stem is a lecture system, where the students follow the lesson by sitting around the teacher who explains the lecture, students look at each book and make notes on it. Bandongan method can be interpreted as a classical learning system in a pondok/madrasa or a crowd, as in the days of the saints, with one teacher explaining the contents of the theme / chapter being discussed in a book ${ }^{33}$.

The learning strategy used is the classical system with lecture and question and answer methods. The teacher explains the material taught by students actively paying attention and the teacher gives the widest opportunity for students to ask questions, ask unclear subjects, the teacher throws the question to the study group to solve together. If the method cannot be solved, the teacher solves it with the students (group learning). After completing the learning process the teacher conducts an evaluation with an oral test or written test to find out the competencies of the students ${ }^{34}$.

The rote method is the willingness of students to learn by memorizing a particular text under the guidance and supervision of the teacher. The students were given the task to memorize various things in a certain period. The memorization that is owned by students is then deposited to the teacher periodically or incidentally depending on the instructions of the teacher concerned. Learning material with the rote method is generally pleasing to the Qur'an, nabwu, sharaf, tajwid or for texts of nahwu, sharaf and figh. In this learning method a student is assigned by the teacher to memorize a certain part or the whole of a book.

\section{METHOD}

This research is a type of field research that is qualitative. Qualitative research is research that describes and describes the results of research objectively of the circumstances and characteristics of the actors found in the field to describe and analyze phenomena, events, social activities, attitudes, beliefs, perceptions, thoughts of individuals, or groups of people. Then the writer uses the descriptive research model qualitative that is described in words according to the opinion of respondents accordingly with research questions ${ }^{35}$.

The descriptive method is finding facts with the right interpretation. This study studies the problems in society, as well as the procedures that apply in the community and certain situations, including the relationship between activities, attitudes, views, and the ongoing process and the influence of a phenomenon. The purpose of this descriptive study is to make

\footnotetext{
33 Ziemek Manfred, Pesantren Dalam Perubahan Sosial (Jakarta: P3M, 1983).

34 Ismail Suardi Wekke and Sanusi Hamid, 'Technology on Language Teaching and Learning: A Research on Indonesian Pesantren', Procedia - Social and Behavioral Sciences, 2nd World Conference on Educational Technology Research, 83 (4 July 2013): 585-89, https://doi.org/10.1016/j.sbspro.2013.06.111; Muhammad Yusuf and Ismail Suardi Wekke, 'Active Learning on Teaching Arabic for Special Purpose in Indonesian Pesantren', Procedia - Social and Behavioral Sciences, The Proceedings of 6th World Conference on educational Sciences, 191 (2 June 2015): 137-41, https://doi.org/10.1016/j.sbspro.2015.04.245.

35 Arikunto Suharsimi, Metode Penelitian Pendidikan dan Pengembangan, 5th ed. (Jakarta: Kencana, 2016); Moloeng Lexy J, Metodologi penelitian Kualitatif, 29th ed. (Bandung: Rosdakarya, 2011); John W. Creswell, Qualitative Inquiry \& Research Design: Choosing among Five Approaches, 2nd ed (Thousand Oaks: Sage Publications, 2007).
} 
a systematic, factual, and accurate description, picture, or painting of the facts, properties, and relationships between the phenomena investigated. ${ }^{36}$

Based on the above, the research approach is a qualitative descriptive approach. According to Isaac and Michel cited by Jalaluddin Rahmat that the qualitative descriptive approach aims to describe systematically, facts, and certain characteristics factually and accurately ${ }^{37}$. This approach also aims to get an in-depth description of speech, writing, and behavior that can be observed from an individuals or groups of people or organizations in certain settings which are examined from a comprehensive perspective.

\section{RESULT AND DISCUSSION}

\section{The aim of learning the Kitab Kuning is for Santri Dayah Darul Huda, Langsa City}

The purpose of learning the Kitab Kuning at Dayah Darul Huda Langsa City is to improve the quality of students in understanding, reading the Kitab Kuning well. as well as being able to understand Islamic laws contained in the Kitab Kunings that have become popular, especially in Aceh, generally dayah (Islamic Boarding School) in Indonesia and the learning of the Kitab Kuning can be applied in everyday life. As the results of the interview with Ustad Zikri that:

"The aim of implementing the Kitab Kuning learning at Dayah Darul Huda Langsa City is to improve the quality of students, especially in the knowledge of Islamic

Religious Education which comes from classical books on students and it is hoped that the creation of a cadre of scholars and Muslims who can be useful in society".

In other words, the purpose of studying the Kitab Kuning at Dayah Darul Huda Langsa City is to increase the awareness of students in carrying out Islamic religious commands and be able to provide information for the public about Islamic religious knowledge and be able to do a lot in the midst of society.

Judging from the content of its meaning, the Kitab Kuning can be grouped into two types, namely: 1) The Kitab Kuning in the form of an offer or the presentation of knowledge in a plain (narrative) such as history, hadith, and interpretation; and 2) the Kitab Kuning that presents the material in the form of scientific principles such as nahwu, fiqh proposal, and must al-hadith (terms relating to the hadith).

The preservation of the Kitab Kuning in the pesantren has been going on continuously, and culturally it has become a special feature of the pesantren to date. Here, the role of pesantren institutions in the classical scientific tradition is very large. The teachings of these classic books on growth have developed colors in the form of certain understandings and value systems. Value systems develop naturally and are rooted in pesantren culture, both in the form of classical books and those born from the influence of the pesantren environment. ${ }^{38}$

The response of students is very good at learning the Kitab Kuning as a lesson that must be followed by students and must pass according to a minimum standard of values determined by the field of curriculum and Dayah teaching. some other responses are good and the learning of the Kitab Kuning can help develop a person's personality and knowledge that is

\footnotetext{
${ }_{37}^{36}$ Emzir, Analisis data: metodologi penelitian kualitatif (Jakarta: Rajawali Pers, 2010).

37 Jalaluddin Rakhmat, Metode penelitian komunikasi: dilengkapi contob analisis statistik. (PT Remaja Rosdakarya, 1999).

${ }^{38}$ Nurul Hanani, 'Manajemen Pengembangan Pembelajaran Kitab Kuning', Dalam Jurnal Realita 15, no. 2 (2017): 1-25.
} 
deeper. The Kitab Kuning must be followed by students because it is one of the lessons included in the core material that can be used as a reference in the development of student knowledge in the midst of society.

The implementation of the Kitab Kuning learning strategy at Dayah Darul Huda Langsa, as expressed by Ustad Zikri is as follows:

"The teacher combines the conventional methods applied in Islamic boarding schools with formal (modern) educational methods, the methods used in the Kitab Kuning learning, namely: the sorogan method, the bandongan method, the lecture method, the discussion method, the demonstration/experiment method, the question and answer method, and the method of recitation (assignment) ${ }^{39}$ "

After the bandongan method is delivered, the teacher immediately explains the meaning contained in the book material through the lecture method, however in the application of this lecture method there are many obstacles such as students tend to be passive and pay less attention to the material presented by the teacher, even though in the delivery the teacher generalizes and the application is good because the teacher has combined some general information related to teaching materials and finally provides conclusions or conclusions on the teaching materials that have been given ${ }^{40}$.

The passivity of the santri when the lecture method (ceramah) is applied is very reasonable, because when the bandongan method is over (students write to give meaning to their book) their physical condition becomes tired and tends to lack concentration and pay less attention to the material presented by the teacher ${ }^{41}$. As with the lecture method, the question and answer method carried out there also experiences the same problem, namely the students are less enthusiastic and less active, this is because in the application of this question and answer method, the teacher does not give a special score to the students who ask questions, so the students are less It is stimulated to ask the teacher and is impressed as a complement and about the silence of most of the students during the question and answer method, it could be because the environmental conditions are not supportive for question and answer, usually this is because the students are embarrassed if the question they are going to ask is wrong or less so that his friends laugh at him.

To overcome the passivity of the santri when participating in learning, a learning method that is centered on the students is also applied, namely students who are active in learning the Kitab Kuning. The goal is that students who are active in learning the Kitab Kuning will be more encouraged in understanding the Kitab Kuning. In this connection, the researcher also conducted an interview with Teacher Muhammad Wali, said that: "In learning the Kitab Kuning, apart from using the traditional teaching method, now it is also using the drill method".

39 Zikir, Interview Tuan Guru Zikir, 2020.

40 Muhammad Amri, Saharuddin Saharuddin, and La Ode Ismail Ahmad, 'The Implementation of Islamic Education: The Process of Instilling Akhlakul Karimah (Noble Characters) for Madrasah Tsanawiyah Students', Tadris: Jurnal Keguruan Dan Ilmu Tarbiyab 4, no. 1 (28 June 2019): 117-25, https://doi.org/10.24042/tadris.v4i1.4070; Muhammad Anas Ma`arif and Muhammad Husnur Rofiq, 'The Role of Islamic Education Teachers in Improving the Character of Nationalism in Boarding School', EDUKASI: Jurnal Pendidikan Islam 6, no. 1 (21 June 2018): 064-078, https://doi.org/10.5281/edukasi.v6i1.323.

${ }^{41}$ Naufal Ahmad Rijalul Alam, 'Strengthening Leadership Culture (The Role of Kyai in Indonesian Pesantren)', At-Ta'dib 13, no. 1 (2018): undefined-undefined, https://doi.org/10.21111/at-tadib.v13i1.1986. 
The dominant method used by teachers is the bandongan method. the teacher conveys the Kitab Kuning material taught through the bandongan method. In applying this method the santri actively follows it, all the santri give meaning to the book which is still empty, and the teacher also submits this method to be more flexible and conditional like the delivery of the bandongan method at the Islamic Boarding School or dayah, meaning the teacher reads the meaning of the book slowly. Students who are late in giving meaning to the book are welcome to ask questions. The teacher is willing to repeat it, according to the author's analysis, the success of the bandongan method is because the students feel the need to complete the meaning of the book so that they know its contents and can read the text.

In the implementation of the learning of the Kitab Kuning in Dayah Darul Huda Langsa City, all Kitab Kuning teachers did not yet apply the discussion method and according to the author's analysis, this was due to the limited time to apply the method. Thus it would be better if the teacher applied it and if indeed there was not enough time to implement this method, the lecturer could place it on extra hours or the teacher held extra hours outside of class time.

The application of teaching methods in the implementation of the learning of the Kitab Kuning in Dayah Darul Huda is not entirely in accordance with the prevailing theory, it is largely due to the lack of lesson hours in the learning of the Kitab Kuning, and the methods implemented in the Dayah Darul Huda Langsa city namely bandongan and sorogan methods, discussion and question and answer. It is expected that the teacher can apply the bandongan method in the learning of the Kitab Kuning, because this method can awaken the cognitive, affective and psychomotor abilities possessed by the santri.

\section{CONCLUSION}

As one of the stakeholders, the community is expected to be able to provide solutions to various educational problems that occur in our country. Education becomes something interesting to talk about it. Education in Islam is a series of human empowerment processes towards taklif (maturity), both mentally and morally, to carry out the humanitarian function carried as a servant before his Khaliq and as a preserver (caliph) to the universe.

Educators who are always involved in the teaching and learning process so that goals can be achieved effectively and efficiently, then mastery of the material alone is not enough. He must master various methods or techniques for delivering the material taught and know the abilities of children who receive. The selection of the right methods and techniques requires special expertise. Educators must be competent to possess and use what procedures will be used. The purpose of learning the Kitab Kuning at Dayah Darul Huda Langsa City is to improve students' quality of understanding, reading the Kitab Kuning well. Students' response is very good at learning the Kitab Kuning as a lesson that must be followed by students and must pass according to a minimum standard of values determined by the field of curriculum and Dayah teaching. 


\section{REFERENCES}

A. Rusdiana. Konsep Inovasi Pembelajaran. Bandung: Pustaka Setia, 2014.

Abdurrahman, Mas`ud. From Haramain to Nusantara: An Intellectual Trail of Pesantren Arcbitects. Jakarta: Kencana, 2006.

Abdurrahman, Nana Herdiana. 'Character Education in Islamic Boarding School- Based Sma Amanah'. Jurnal Pendidikan Islam 2, no. 2 (21 June 2016): 287-305. https://doi.org/10.15575/jpi.v2i2.791.

Abidin, Yunus. Desain Sistem Pembelajaran Dalam Konteks Kurikulum 2013. Cetakan kesatu. Bandung: Refika Aditama, 2014.

Al Idrus, Ali Jadid. 'Modernisasi Sistem Manajemen Dan Kurikulum Pondok Pesantren'. Jurnal Penelitian Keislaman 12, no. 2 (2016): 141-154.

Alam, Naufal Ahmad Rijalul. 'Strengthening Leadership Culture (The Role of Kyai in Indonesian Pesantren)'. At-Ta'dib 13, no. 1 (2018): undefined-undefined. https://doi.org/10.21111/at-tadib.v13i1.1986.

Amri, Muhammad, Saharuddin Saharuddin, and La Ode Ismail Ahmad. 'The Implementation of Islamic Education: The Process of Instilling Akhlakul Karimah (Noble Characters) for Madrasah Tsanawiyah Students'. Tadris: Jurnal Keguruan Dan Ilmu Tarbiyah 4, no. 1 (28 June 2019): 117-25. https://doi.org/10.24042/tadris.v4i1.4070.

Amrullah, Abdul Malik Karim. 'Kontribusi Karya Tulis Kiai Basori Alwi Terhadap Pengembangan Wawasan Keagamaan Masyarakat'. Ulul Albab Jurnal Studi Islam 13, no. 1 (17 September 2013): 35-48. https://doi.org/10.18860/ua.v0i0.2381.

Arwani, Wawan. 'Kiai Pesantren Dan Kontribusinya Dalam Mengembangkan Pluralitas Keberagamaan Dan Toleransi Di Kabupaten Cirebon'. Holistik 15, no. 1 (5 April 2016). https://doi.org/10.24235/holistik.v15i1.434.

Asrohah, Hanun. 'The Dynamics of Pesantren: Responses Toward Modernity and Mechanism in Organizing Transformation'. Journal of Indonesian Islam 5, no. 1 (1 June 2011): 66-90. https://doi.org/10.15642/JIIS.2011.5.1.66-90.

Azra, Azyumardi. Pendidikan Islam: Tradisi Dan Modernisasi Di Tengab Tantangan Milenium III. Jakarta: Kencana, 2012.

Bachrong, Faizal. 'Pembelajaran Kitab Kuning Pada Pondok Pesantren Hidayatullah Ternate'. PUSAKA 6, no. 1 (26 November 2018): 105-16. https://doi.org/10.31969/pusaka.v6i1.43.

Barmawi, Muhammad. 'Peranan Lingkungan terhadap Semangat Belajar dalam Khazanah Kitab Kuning'. Edukasia Islamika, 2 March 2017, 134-60. http://ejournal.iainpekalongan.ac.id/index.php/edukasiaislamika/article/view/773.

Biwer, Felicitas, Mirjam G. A. oude Egbrink, Pauline Aalten, and Anique B. H. de Bruin. 'Fostering Effective Learning Strategies in Higher Education - A Mixed-Methods Study'. Journal of Applied Research in Memory and Cognition 9, no. 2 (1 June 2020): 186203. https://doi.org/10.1016/j.jarmac.2020.03.004.

Brown, H. Douglas. Principles of Language Learning and Teaching. Prentice-Hall, 1987.

Brown, Wendy, Jan Dobbernack, Tariq Modood, Glen Newey, Andrew F March, Lars Tønder, and Rainer Forst. 'What Is Important in Theorizing Tolerance Today?' 
Contemporary Political Theory 14, no. 2 (April 2015): 159-96. https://doi.org/10.1057/cpt.2014.44.

Chairi, Effendi. 'Pengembangan Metode Bandongan Dalam Kajian Kitab Kuning Di Pesantren Attarbiyah Guluk-Guluk Dalam Perspektif Muhammad Abid al-Jabiri'. Nidhomul Haq: Jumal Manajemen Pendidikan Islam 4, no. 1 (15 March 2019): 70-89. https://doi.org/10.31538/ndh.v4i1.233.

Creswell, John W. Qualitative Inquiry \& Research Design: Choosing among Five Approaches. 2nd ed. Thousand Oaks: Sage Publications, 2007.

Damanhuri, Damanhuri. 'Kitab Kuning: Warisan Keilmuan Ulama Dan Kontekstualisasi Hukum Islam Nusantara'. 'Anil Islam: Jurnal Kebudayaan Dan Imu Keislaman 10, no. 2 (1 December 2017): 234-61. https://doaj.org.

Dell' Olio, Dr. Jeanine M. M, and Dr. Tony Donk. Models of Teaching: Connecting Student Learning with Standards. Thousand Oaks: SAGE Publications, 2007. http://public.eblib.com/choice/publicfullrecord.aspx?p=996882.

Dhofier, Zamakhsyari. Tradisi pesantren: studi pandangan hidup kyai dan visinya mengenai masa depan Indonesia. Cet. 8 rev. Jakarta: LP3ES, 2011.

Emzir. Analisis data: metodologi penelitian kualitatif. Jakarta: Rajawali Pers, 2010.

Fitriyah, Lailatul, Marlina Marlina, and Suryani Suryani. 'Pendidikan Literasi Pada Pembelajaran Kitab Kuning Di Pondok Pesantren Nurul Huda Sukaraja'. Titian Ilmu: Jurnal Ilmiah Multi Sciences 11, no. 1 (1 January 2019): 20-30. https://doi.org/10.30599/jti.v11i1.351.

Hanani, Nurul. 'Manajemen Pengembangan Pembelajaran Kitab Kuning'. Dalam Jurnal Realita 15, no. 2 (2017): 1-25.

Hergenhahn, B. R, and Matthew $\mathrm{H}$ Olson. Theories of learning = teori belajar. Translated by Triwibowo. 6th ed. Jakarta: Prenada Media Grup, 2016.

Indra, Hasbi. 'Salafiyah Curriculum at Islamic Boarding School in the Globalization Era'. TARBIYA: Journal of Education in Muslim Society 4, no. 1 (13 June 2017): 74-88. https://doi.org/10.15408/tjems.v4i1.4960.

Jabbar, Moh Tasi'ul, Wahidul Anam, and Anis Humaidi. 'Upaya Kiai Dalam Meningkatkan Kemampuan Membaca Kitab Kuning'. EDUDEENA: Journal of Islamic Religious Education 1, no. 1 (29 November 2017). https://doi.org/10.30762/ed.v1i1.446.

Lexy J, Moloeng. Metodologi penelitian Kualitatif. 29th ed. Bandung: Rosdakarya, 2011.

Ma'arif, Muhammad Anas, and Muhammad Husnur Rofiq. 'The Role of Islamic Education Teachers in Improving the Character of Nationalism in Boarding School'. EDUKASI: Jurnal Pendidikan Islam 6, no. 1 (21 June 2018): 064-078. https://doi.org/10.5281/edukasi.v6i1.323.

Ma'arif, Muhammad Anas, and Nur Silva Nabila. 'The Contribution Of Kiai Munawwar Adnan Kholil Gresik On Islamic Education'. Tribakti: Jurnal Pemikiran Keislaman 31, no. 2 (20 July 2020): 218-36. https://doi.org/10.33367/tribakti.v31i2.1126.

Ma'arif, Syamsul. 'Education as a Foundation of Humanity: Learning from the Pedagogy of Pesantren in Indonesia'. Journal of Social Studies Education Research 9, no. 2 (12 May 2018): 104-23. https://bulenttarman.com/index.php/jsser/article/view/256. 
Madjid, Nurcholish. 'Merumuskan Kembali Tujuan Pendidikan Pesantren'. Dalam Dawam Rahardjo, Pergulatan Dunia Pesantren: Membangun Dari Bawah. Jakarta: P3M, 1985.

Mahfudh, K. H. M. A. Sahal. Nuansa Figh Sosial. Lkis Pelangi Aksara, 2003.

Manfred, Ziemek. Pesantren Dalam Perubahan Sosial. Jakarta: P3M, 1983.

Nur, Ismet. 'Modernization of Integrated Dayah Educational System in Darul Mukhlisin Burnijimet'. Episteme: Jurnal Pengembangan Ilmu Keislaman 14, no. 2 (1 December 2019): 333-47. https://doi.org/10.21274/epis.2019.14.2.333-347.

Nurhayati, Eti, and Yayah Nurhidayah. 'Multicultural Value in the Traditional Islamic Boarding School, Bina Insan Mulia (BIMA), Cirebon, Indonesia'. Nadwa 13, no. 1 (29 August 2019): 165-78. https://doi.org/10.21580/nw.2019.1.1.3509.

Qomar, Mujamil. Pesantren: dari transformasi metodologi menuju demokratisasi institusi. Ciracas, Jakarta: Erlangga, 2005.

Rahman, Nazarudin. Regulasi Pendidikan: Menjadi Guru Profesional Pasca Sertifikasi. Yogyakarta: Pustaka Felicha, 2009.

Rakhmat, Jalaluddin. Metode penelitian komunikasi: dilengkapi contoh analisis statistik. PT Remaja Rosdakarya, 1999.

Rasyidin, Al. 'Pembelajaran Kitab Kuning Di Pesantren Musthafawiyah, Mandailing Natal'. Journal of Contemporary Islam and Muslim Societies 1, no. 1 (1 September 2017): 41-67. https://doi.org/10.30821/jcims.v1i1.324.

Rijal, Akh Syaiful. 'Pemakaian Kitab Kuning Dalam Meningkatkan Mutu Pembelajaran Fiqh Di Madrasah Tsanawiyah Berbasis Pesantren Di Pamekasan’. Muslim Heritage 2, no. 2 (1 January 2018): 293-316. https://doi.org/10.21154/muslimheritage.v2i2.1113.

Rusdi, Rusdi. 'Pengembangan Metode Pembelajaran Kitab Kuning Dalam Mencetak Ahli Fiqh'. An Nuba: Jurnal Kajian Islam, Pendidikan, Budaya \& Sosial 5, no. 1 (1 July 2018): 35-66. https://doaj.org.

Serpil, Harun. 'Book Review Student-Teacher Interaction in Online Learning Environments'. The Turkish Online Journal of Distance Education 18, no. 2 (1 April 2017): 202-7. https://doaj.org.

Suharsimi, Arikunto. Metode Penelitian Pendidikan dan Pengembangan. 5th ed. Jakarta: Kencana, 2016.

Syakroni, Agus, Zamroni, Chusnul Muali, Hasan Baharun, Muh Zainuddin Sunarto, Bisri Musthofa, and Muallim Wijaya. 'Motivation And Learning Outcomes Through The Internet Of Things $\$$ mathsemicolon\$ Learning In Pesantren'. Journal of Physics: Conference Series 1363 (November 2019): 012084. https://doi.org/10.1088/17426596/1363/1/012084.

Thoyib, Muhammad. 'Charismatic Leader on Developing Visionary Pesantren Bidayatul Hidayah in East Java: Profile and Strategy of Dr. KH. Ahmad Musthofa Kamal's Leadership'. Jurnal Pendidikan Islam 7, no. 1 (27 August 2018): 79-99. https://doi.org/10.14421/jpi.2018.71.79-99.

Van Bruinessen, Martin. Kutab Kuning Pesantren dan Tarekat. 1st ed. Yogyakarta: Gading Publising, 2012.

—. Tarekat Naqsabandiyah DI Indonesia. 1st ed. Bandung: Mizan, 1992. 
Venkatraman, Sitalakshmi. 'A Framework for Implementing TQM in Higher Education Programs'. Quality Assurance in Education 15, no. 1 (1 January 2007): 92-112. https://doi.org/10.1108/09684880710723052.

Wekke, Ismail Suardi, and Sanusi Hamid. 'Technology on Language Teaching and Learning: A Research on Indonesian Pesantren'. Procedia - Social and Behavioral Sciences, 2nd World Conference on Educational Technology Research, 83 (4 July 2013): 585-89. https://doi.org/10.1016/j.sbspro.2013.06.111.

Yusuf, Muhammad, and Ismail Suardi Wekke. 'Active Learning on Teaching Arabic for Special Purpose in Indonesian Pesantren'. Procedia - Social and Behavioral Sciences, The Proceedings of 6th World Conference on educational Sciences, 191 (2 June 2015): 137-41. https://doi.org/10.1016/j.sbspro.2015.04.245.

Zikir. Interview Tuan Guru Zikir, 2020. 